\title{
Urban Park of the University City Lot of Passo Fundo, RS, Brazil: Example of Environmental Recovery (Five Years of Research)
}

\author{
Alcindo Neckel $^{1, *}$, Luciana Londero Brandli ${ }^{2}$, Pedro Domingos Marques Prietto ${ }^{2}$ \\ ${ }^{1}$ Departmentof Geography, Federal University of Rio Grande of Sul, Brazil \\ ${ }^{2}$ Post-graduation in Engineering, Infrastructure and Environment, University of Passo Fundo, Brazil \\ *Corresponding author: alcindoneckel@yahoo.com.br
}

Received April 19, 2013; Revised October 17, 2013; Accepted November 15, 2013

\begin{abstract}
The objective of this project was to turn an impacted area at The University City Lot in Passo Fundo, Brazil, into an urban park through the local community effort, since urban green areas play an important role in environmental quality and sustainability. Qualitative research methods were applied and a plan of action to present to the municipal authorities was elaborated in a participatory manner, which included several environmental perception surveys, soil profile and water quality parameters identification, remediation and preventive actions to increase soil and water quality. Overall, research results in 2005 and 2010 have shown greater native plant diversity with evidence of improved soil and water quality, contributing to the environmental recovery and the community quality of life.
\end{abstract}

\section{Keywords: Brazilian parks, urban parks, environmental recovery, environmental preservation}

Cite This Article: Alcindo Neckel, Luciana Londero Brandli, and Pedro Domingos Marques Prietto, "Urban Park of the University City Lot of Passo Fundo, RS, Brazil: Example of Environmental Recovery (Five Years of Research).” Applied Ecology and Environmental Sciences 1, no. 6 (2013): 113-119. doi: 10.12691/aees-1-6-3.

\section{Introduction}

The unorganized growth of urban areas has several negative effects on the environment as well as on people's life quality. These effects can be seen during the urbanization process because of the increase of deforestation and an increasing number of buildings. In order to reduce environmental impacts, new strategies have to be adopted to preserve urban parks. For instance, the University City Lot (UCL), an urban park located in District Petrópolis, in Passo Fundo City, RS State, Brazil, has been jeopardized by unplanned urbanization. At the park, typical environmental issues can be found such as illegal garbage disposal and the removal of top soil in an attempt to level out the area by civil construction. Both the misuse of it and the poor management of the area are evident. The underestimation of ecological services and the process of housing market speculation are also noticeable in this area. Overall, the area has been functioning as an open and irregular landfill as well as a shelter for homeless people and delinquents for many years. It seems that the area was abandoned by the public sector with noticeable soil degradation and water contamination, creating conditions for disease proliferation. Few native species can be found in the area involved in natural ecological succession. It is noteworthy to mention that green areas, that have been historically misused and mismanaged, cannot provide an ecological service in both urban and environmental context.

The UCL Urban Park has improved its condition since the beginning of this study, that is, in 2005, due to the diligent work of local residents who became aware of the necessity for preserving and managing urban green areas, which would be both public and private sectors responsibility. The initial project of local empowerment was developed and implemented over two years, to begin the area's environmental recovery. Part of the methodology included the transplanting of approximately 500 tree seedlings; the adoption and implementation of buffer strips located near water sources (according to the Brazilian environmental legislation guidelines); and the designation of an specific area for recreation, which was dedicated to the local community to fulfill the role of an urban park. Through these actions, the local community exposed their perceptions and expectations for the park. Currently, the area is listed as an urban park in the city reports, providing means to increase people's quality of life as park users. This recognition towards the park is important since there are no many green areas in Passo Fundo. Furthermore, the existent areas show noticeable ecological degradation. If the preservation and maintenance of such areas is not successful, there is a risk of losing them. Such a loss could result in a reduction of life quality in the city caused by the absence of public spaces for recreation [1].

Additionally, new efforts were proposed in 2010, aiming at furthering the preservation of the UCL urban 
park. These efforts are also listed in detail and further discussed in this paper.

\section{Urbanization and Environmental Changes}

The foundation and development of Brazilian cities has built a variety of contrasts that are typical in developing countries, where there is no territorial organizational urban management models. The urban community became larger than the rural community, and consequently, the cities became areas of large industrial growth, increasing cash flow and a population that demands a higher level of organization. [2] Points out that with people's migration to the city, the expansion of peripheral areas happened very rapidly, especially in those peripheries surrounded by metropolitan areas. A process of the metropolis enlargement via demographic explosion has been observed, and the emergence of new centers or sub centers along with shifting migratory fluxes caused growth in certain population segments and exclusion of others. Therefore, segregation and differentiation in these newly settled areas can occur [3].

However, over the last 30 years,city officials have focused on effective urban planning. Among them, there are intellectuals from left leaning liberal parties and their conservative counterparts [4]. The man cannot act in a space without organization because it is necessary to first function in the geographic space before focusing on either production or business activity, in a way that the geographical space precedes the economic space. Therefore, the economic space has an increasingly elaborate content because it can be chosen and is located inthe geographic space, becoming part of it. Therefore, the planning and management of urban areas can be more than organizational strategies that lead to the urban development [4]. The quality of urban environments is extremely important as well, and it should be improved through education, entertainment, safety and the contact with nature [5]. In addition, urban parks users need to be able to have positive experiences and comfort in order to enjoy nature. Levels of comfort vary from one person to another as well as successful environmental conditions to create positive experiences.

According to [6], different regions of a city experience conditions that will determine the use of a park. However, there are limitations for the use that can be caused by production, consumption, and habitation. Classify these areas in zones of use requires human appropriation of an entire plot of land to divide it according to personal perspectives. The geographyrole is as important as environmental concern. It is noteworthy to mention that regional geographic knowledge hashistorically been emphasizing the environment due to the fact that geography can be understood as the study of landscapes, environment, and environmentalism. These three topics have always been present in geographic analysis and knowledge of nature became part of the lesson plans and structure of the geography curriculum [7].

The main objective of the laws that protect the environment is to control the several human activities to avoid constant degradations [8]. The awareness regarding environmental complexity can be used, in this sense, to internalize ecological conditions towards sustainability in the dynamics of capital. Awareness and knowledge is also important to develop an ecological rationality that contradicts capitalism [9]. Green areas become a key element in cities since they can create room to expand the so called human-nature relationship. Moreover, green areas can potentially serve to improve human relationships [10].

Despite the recognition of potential benefits of maintaining or recovering green areas for recreation, soil use and conservation, water supply protection and sewage treatment, risk management, litter prevention and proper waste management have not been taken into account as a priority by the majority of the public power members [11]. To guarantee the responsibility for the proper management of green areas, the Brazilian Constitution requires a "Master Plan" for cities where there are over 20,000 inhabitants. This Master Plan has been defined as the basic tool for the development of urban expansion and has to be used as a parameter to ensure social function as well.

Negative environmental impact can occur due to the sum of factors such as the misuse of the soil. The Urban land use encompasses a wide range ofareas, including commercial, industrial, residential, and recreational but the disturbance of native soils predominates due to high population density. This disturbance can occur because of the following actions: filling or grading of areas in an effort to level landscapes for homes, buildings or ball fields, filling areas that are wet or have other undesirable soil characteristics or are used to dispose materials such as dredge spoils and coal ash, mixing of soil horizonsor removal of topsoil, addition of plant growth media, and atmospheric deposition of airborne materials. Moreover, soils in urban areas have been found to have higher $\mathrm{pH}$ values than undisturbed natural soils due to the addition of basic actions from road salts, concrete, plaster and other anthropogenic materials [12].

Local water sources are also highly impacted through the urban expansion. The presence of localized water sources suchas humid zones inside a specific area do not necessarily prevent urban expansion, when the occupation is illegal and/or not reported to the local authorities [13] mainly. Given the lack of an adequate planning for sewage, wetlands and streams are often overloaded with unnatural influxes of contaminated water due to both pluvial precipitation and disposal of water with high amounts of suspended particles caused by impermeable surface and soil conditions [14]. Moreover, as the growth of cities in developing countries is often not accompanied by infrastructure of public utilities and services such as water treatment and sewage, a variety of wastes from both housing and local industry often end up flowing directly into natural drainage systems. Inputs of chemical compounds and organic matter into wetlands are common, filling them with foul odors, changing the population of living organisms in the water column, affecting vegetation type, cover, and distribution and causing eutrophication. In addition to such damage, the local vegetation and natural landscape is generally significantly depreciated or totally removed in order to build roads and houses. As a consequence, the fauna habitat is jeopardized, forcing original local animal populations to adapt to these changes, migrate or even disappear. 
The process of city expansion and incorporation of new spaces for buildings and industries changes the landscape and modify the urban environment [4] in many aspects; mainly through construction sites, vegetation clearance, and by the misuse of soil and water resources [12]. Processes such as erosion greatly modify urban soils and their use [15]. The bigger the city, the more likely it is to have an in-depth complexity regarding the severity of problems. Such evidence can be used to make an analysis of the level of environmental degradation and impact, as well as to create strategies of intervention to promote more sustainable urban environments. People's engagement is essential to assure the proper use of green areas in urban environments as stated in the Master Plan of the city.

Fortunately, in the past four decades, information technology as well as environmental and social awareness have brought new perspectives to people's lifestyle, pondering about the exponential development of industrial technologies, which appear to be the main driving force behind urban expansion [16]. Moreover, despite the fact that cities differ in size, activity type and location, similarities exist among them, such as unemployment, housing, transportation, recreation, water and sewage treatment, education and health issues. All these areas demand work and attention from the local municipal power.

\section{Urban Parks}

The first report of urban parks occurred in England at the end of the 18th century as green areas of common use for recreation. Later on, this concept was incorporated into the daily life of city dwellers in the American and French populations of the $19^{\text {th }}$ century [17]. In Brazil, the importance of such areas is guaranteed by law in the Federal Constitution of 1988. The environmental concerns were explicit in the national legislation and this made Brazilian states and cities to create effective tools to preserve green areas. Promoting the sustainable use of local lands, while minimizing local and regional environmental impacts due to occupation, has become a common goal [18].

According to [19], the Brazilian territory is governed by strict environmental legislation at federal, state and municipal levels. However, environmentally effective protection depends, not only, but mostly on strong public support. Green areas are natural ecosystems that have to be studied in a holistic way, respecting the complex interactions present in them. Nowadays, some public sectors have been observed seeking partnerships with other institutions and non-governmental organizations in order to increase environmental protection [18]. When such partnerships are built urban parks become areas of natural resources conservation, such as water, air, flora, fauna and climate. Through the urbanization process, all of these elements suffered some degree of modification through changes in the landscape, use of soil, local fauna, hydrology and microclimate changes [1].

According to [19], the definition of an urban park is a delimited space within the urban limits that contains some vegetation and is destined for public use and recreation, community involvement, and educational and cultural activities. Therefore, the state must guarantee the protection of the park because it becomes an area of extreme importance, for both the city and the region in which it is located. Urban parks can visually improve an overwhelmed and cluttered urban area in which buildings and dwellings are very closed; thereby contributing to a marked increase in the quality of life of local inhabitants $[1,17,20,21]$.

In addition, studies have shown a general increase in the recognition of benefits derived from urban parks. For instance, a study made by [22] in Maringá City, Paraná State, Brazil, evaluated sixteen urban parks that strove to improve their local landscape management through the use of vegetative belts and buffer strips, linear areas along the water sources such as streams, reforestation and air monitoring and the implementation of ecological sidewalks. Among the results, the authors pointed out that the urban parks serve as windbreaks and protect city buildings from the dispersion of pollution by local industries. Another study in São Paulo conducted by [23] has shown that the majority of families using urban parks have children, so they go there for recreation mainly.

However, sometimes members of the community are not aware that the park is in fact a public land overseen by the local municipality and they misuse the area because they think it is an unclaimed land. Such misuse often results in the environmental degradation. To turn the situation worse, the local municipality can at times misuse the area as well. According to [24], Botafogo Urban Park, which also canalized stream Botafogo into a canal, also suffered the environmental impacts due to the construction on Botafogo Avenue, this resulted in great environmental degradations to the park. Levels of disturbance and damage differ widely, but actions are often quite similar in other Brazilian cities. Urban park Dom Pedro II located in São Paulo State, urban park Treze de Maio in Recife State, and Belo Horizonte Municipal Park in Minas Gerais State, are also other examples of this situation. Park degradation can also be seen in small towns such as Ouricuri City in the country of Pernambuco State. In this town, a small park located across from the Nordeste do Brasil Bank (BNN) suffered many acts of vandalism and negative environmental impact by local people [24]. Frequently, the municipal authorities try to avoid the noticeable impact of degradation by sending maintenance and repair crews to the area; which adds to the city and state budget costs. Such expenses could be avoided if local schools were more engaged in these green areas to teach environmental education to their students as well as to develop an environmental consciousness [1].

Urban park managers must keep a dataset with information collected over the years to build up a resource for other managers facing similar issues [25]; and better yet, implementing a management plan for an urban park that can serve as an efficient tool to promote adequate maintenance and park conservation [21]; which is now recognized to be essential [19]. The management plan includes many environmental and technical aspects while focusing on social issues, such as the violence committed in the park borders. [26] have been researching the creation and implementation of Peace Urban Parks. One of their research targets was Tijuca National Park, located in Rio de Janeiro State, Brazil, which has considerably high rates of violence. The proposal was to work with 
offenders in an effort to promote awareness of the importance of green areas protecting local biodiversity within urban areas located in conflict zones. [20] Points out that actions to promote environmental consciousness using the idea of green areas as public patrimony have become important in justifying urban sustainability. However, according to [27] people who live in the park surroundings need to be engaged and politically mobilized in order to maintain it and contribute to effective ecological preservation. [28] Emphasize that financial investments are also necessary for the benefit of park users.

\section{Materials and Methods}

\subsection{Area of study}

The UCL is located in Passo Fundo City, in the Northern part of RS State, Brazil. Passo Fundo has the following geographic coordinates $28^{\circ} 07^{\prime}$ East $28^{\circ} 25^{\prime}$ latitude South and $52^{\circ} 17^{\prime}$ and $52^{\circ} 41^{\prime}$ longitude West. The city borders are Pontão, Sertão, Coxilha, Carazinho, Ronda Alta and Santo Antônio do Planalto to the North; Ernestina and Nicolau Vergueiro to the West; Marau to the South; and Mato Castelhano to the East. It is the largest city in the Mid-Plateau region with a population of 187,507 people according to the 2010 census [29]. This area has a geomorphologic structure derived from deep basaltic spills, with well-drained soils classified as latosols. The landscape has many rolling hills similar to the Palouse region of Eastern Washington State in the U.S. The local hydrographic network consists of Passo Fundo, Taquari, Jacuí and Várzea rivers as well as Miranda, Pinheirinho, Passo do Herval, Chifroso, Conceição, Engenho Velho and Santo Antonio streams. The park is located on a land, which is owned by the UCL and contributes via wetland areas to the waters of the Invernadinha stream, which is a tributary of the Passo Fundo River, located in the southeast of this area.

The specifics on the study area report $17.834 \mathrm{~m}^{2}$, located between East Avenida Brasil (Brazilian Avenue) and BR 285, near the University of Passo Fundo, at São José Village. There are 33 houses at UCL, in which a variety of families of diverse backgrounds, different social classes and varying employment status reside. These families are farmers, owners of small businesses, teachers, public and private employees as well as students and contractors. There are six streets within this village and the area was determined to be the community's responsibility upon implementation of the urban park.

\subsection{Research Strategies}

In order to make the park area meet its urban and environmental function, the following strategies were established with the community, and they were implemented over the course of five years (from 2005 to 2010).

a) Conducting a bibliographic data search: papers and articles from authors who revealed urban tendencies and urban area usage were identified, using key words that closely matched the condition of UCL Urban Park. This action was supported by local community members beginning with the final course work for a geography degree, followed by a Master's thesis. Local law offices were also used as a source of information and documentation.

b) Area inventory: topographic tools and visual descriptions were used as research methods.

c) Soil samples were collected in different parts of the park at two depths $(0-20 \mathrm{~cm}$ and $20-40 \mathrm{~cm})$. The samples were then analyzed at the Laboratory of Soil at the University of Passo Fundo, following protocols described in the Chemical and Soil Fertility Commission of the states of Rio Grande do Sul and Santa Catarina (CQFSRS/SC, 2004).

d) Social and economic research: over 2005 and 2007, a questionnaire was developed and randomly given to members of 33 residences within the community as a social research tool to collect data regarding the social and economic aspects of the park as well as the environmental perception of park users.

e) The results were compiled and analyzed to identify / verify the main problems and corresponding management techniques to aid the recovery of the area.

f) Data collection: an evaluation of the park's importance for the residents of Passo Fundo was studied. 22 sections were identified in the city (Figure 1). Sections $01,02,03,04,05,07,11,12,18$ and 20 were randomly chosen to be sampled with a questionnaire (Table 1). Overall, 338 houses were sampled to facilitate an adequate sample size. Passo Fundo has about 187,507 inhabitants and a total of 48,228 households [29]. In addition, random sampling of residences in different areas of the City of Passo Fundo provided a significant representation of the people living in the area as potential urban park users.

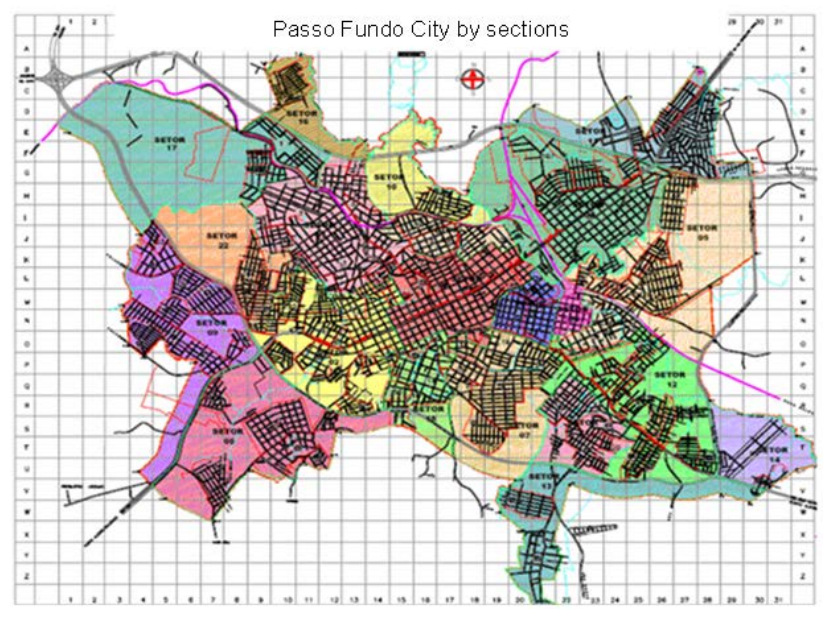

Figure 1. Map of the City of Passo Fundo divided by sections. Each color corresponds to a numbered section (SECTOR) [30].

The questionnaires were divided into two parts: socialeconomics (including seven questions) and environmental perceptions (including 14 questions). The householders were asked about the willingness to pay for improvements, maintenance, and conservation of the park. Further inquiries were conducted in response to environmental improvements made at the urban park as well as suggestions for future projects to promote the environmental preservation of the LUC urban park. 
Table 1. Questionnaires distribution by section and Neighborhoods

\begin{tabular}{|c|c|c|}
\hline $\begin{array}{l}\text { Section } \\
\text { Number }\end{array}$ & Neighborhoods & $\begin{array}{c}\text { Questionnaires } \\
\text { Applied }\end{array}$ \\
\hline 01 & Downtown & 132 \\
\hline 02 & Boqueirão, Operária, Menino Deus, Berthier and Sechi & 54 \\
\hline 03 & Vera Cruz, Nonoai, Dona Eliza, Leão XIII and São Bento & 47 \\
\hline 04 & Petrópolis (containing the Loteamento Cidade Universitária Urban Park) and Invernadinha (Industrial District) & 29 \\
\hline 05 & $\begin{array}{c}\text { São Luiz Gonzaga, Parque Farroupilha, Manoel Corralo, Nova Estação, Entre Rios, Ferroviária, Isabel, Ferroviária } \\
\text { and Parque Bela Vista }\end{array}$ & 23 \\
\hline 07 & Lucas Araújo, Schel, Reis, Simon, Carmen and Padre Don Rodolfo & 22 \\
\hline 11 & São José (including University of Passo Fundo campus), Leonardo Ilha I and II and Brigada Militar & 25 \\
\hline 12 & São José, Ricci, J. André Rebechi, Copacabana, Cezar Santos, São Cristóvão II, Via Sul and Santo Antônio & 28 \\
\hline 18 & Luíza, Tupinambá, Jardim, Ambrosina, Boa Vista, Guilherme Morch and Edu Reis & 25 \\
\hline 20 & Santa Maria, Reinaldo Patussiand Nova & 15 \\
\hline & & 338 \\
\hline
\end{tabular}

\section{Analysis and Results}

Overall, the residents of Passo Fundo have shown a general increase on environmental concerns; questionnaires that originated with the 33 houses of the UCL have revealed some specific opinions against the environmental degradation of the urban park. $43 \%$ had been living in the area for less than 5 years, 21\% had resided in the area between 6 and 10 years, 15\% between 11 and 15 years, $15 \%$ between 16 and 20 years, and 6\% did not answer. This data leads us to conclude that the area is continuously growing. There are records of the environmental degradation before the beginning of the urbanization process, and theoretically, the process of urbanization itself would take care of some of the negative impacts if planning was consistent [15].

Health agents are an important part of teaching the community about safe environments, but only $21 \%$ of interviewed people reported that they had received the visit of a health agent. When they were asked about garbage disposal service, all interviewees mentioned that this service is regularly offered in their area, even though litter is readily visible on the streets and in the park limits as well. There is a possibility that the garbage found in the park comes from outsiders who consider the park as an empty area to litter. To avoid such behavior, it is necessary to make them aware of environment problems. In this sense, a promising idea for the area is the collection of recyclables and household waste on separate days. Interviewees made clear their dissatisfaction regarding the public power's passiveness. The overwhelming opinion of respondents is that the area has not been seen as a priority in this regard. A joint effort between community leaders and a local housing association may be the most efficient way to accomplish the residents' stated goals. $100 \%$ of those interviewed stated that they are committed to participate in all necessary steps required for the park's improvement. However, they also requested in-kind support from the public power and local government.

Regarding the impacts of urbanization on the environment, and having the urban park as an example, the community made the following observations:

- Mice, mosquitoes, cockroaches, snakes, and other small animals are present and contribute to the local proliferation of disease;

- This area has been used as a shelter by delinquents and thieves;
- The park has been misused through recreational activities by outside users who do not reside in the local community;

- Despite the area potential to increase surrounding property values and attract new users, it has been abandoned by the public power and now has no clear purpose;

- There is evidence of preservation of some trees and water resources but other negative environmental impacts should stop, the entire area should be reforested, and the water resources preserved;

- This area can contribute significantly to increase the users' quality of life;

When observing all responses, it can be concluded that there is a strong community awareness regarding the area potential, not only for the local neighborhood but also for the entire city. The recognition of environmental services, through the preservation of water resources that directly flow into Passo Fundo River, was mentioned. The answers also indicated that historically, this area was not considered as priority by city managers as evidenced by the disorganized and unplanned urbanization process. A list of the park potential and the community association's resources was described by the people who were interviewed. Using this information, the following strategies were proposed and implemented in order to facilitate the environmental recovery of the urban park, to wit: (1) The protection of water resources through the implementation of buffer strips in zone 1a (green dots); (2) The reforestation of green areas in zones $1 \mathrm{a}$ and $2 \mathrm{~b}$ and (3) The management of the recreational area in the northern part of zone 2a. Strategies for recovering zone 1a included the removal of any foreign material, such as trash, from the natural area; as well as the transplantation of native tree species and the removal of exotic species, such as pine trees and eucalyptus, in order to reduce environmental competition. Reforestation also took place within the water resources area in a radius of $50 \mathrm{~m}$ around streams, lakes and rivers, according to the Brazilian environmental code (Legislation 7803, July $18^{\text {th }} 1989$ ).

The implementation of recovery strategies were supported by the local community association. Opting for the reforestation with native species was the quickest way to improve soil characteristics while avoiding chemical inputs. Also, native species are more suitable for the specific climate and local characteristics of the area. Selecting from a wide range of native species, growth patterns, ecological fitness and seedling availability were the search parameters used to determine what species to use. Native plant seeds and seedlings were donated by the 
public power. [14] emphasizes a bioengineering method that allows for the development of soil coverage and protection in a short amount of time. The new seedlings will produce organic matter, adding carbon to the soil and recycling other essential elements through their roots. In this sense, general chemical and physical properties of the soil will improve the ability to retain water and nutrients, and the rates of erosion will be lessened [15]. It is noteworthy to mention that climax native vegetation, such as Lueheadivaricata, Laurusnobilis, Cedrellafissilis, Apuleia Leiocarpa, Tabebuiachrysotricha, Tabebuiaimpetiginosa, Myrocarpusfrondosus and Albiziapolycephala require more favorable conditions to establish. Besides reducing erosion, climax vegetation provides a microclimate and habitat for native fauna, mainly attracting bird species that are attracted to the new seed source [14]. The seedlings were transplanted along with additional organic matter. Irrigation was not possible due to the lack of infrastructure. Nutrient, water and light competition with other germinating species was monitored by the community.

Planning and soil preparation was based in a mixed model, using pioneer species, secondary species and climax vegetation within a linear space of $4 \times 4 \mathrm{~m}$ in zones $1 \mathrm{a}$ and $2 \mathrm{~b}$. This is the best method for species introduction in small areas, allowing 4,000 plants/ha. Paspalumnotatum, a native grass, was planted along the borders to aid in: maintaining the area, delaying or preventing germination of other species. In zones $1 \mathrm{a}$ and $2 \mathrm{~b}$, climax species and other native trees such as Erythrina crista-galli, Eugenia uniflora, Campomanesiaxantho carpa, Mimosa scabrella and Araucaria angustifolia were also utilized in the buffer strips near the park's water resources. A total of 500 seedlings were transplanted to contribute to the urban park's local biodiversity, aiming at recovering wetland areas as well as helping to enhance soil structure, ornamentation of landscape for recreation, and providing an environment to improve the users' quality of life.

Regarding strategies to improve recreational aspects of the urban park, the development of a playground, trails and pedestrian pathways were proposed. Its implementation has been slow due to the high degradation of the green area that makes it difficult for trails. Financial and technical resources to follow up with the overall strategy are also lacking. The local community has ranked this project as a very high priority and individual community members and local groups have been working in this area as time allows.

\subsection{Social and Economic Aspects of the Area}

A social and economic investigation was conducted in 2010 in order to characterize the potential UCL urban park users in Passo Fundo city. Inquiries were also made as to their awareness of the existence of this area. A total of 388 participants, 169 female and 169 male, were part of this research. Participant ages ranged between 16 and 21 years (3\% women and 8\% men), 21 and 28 years (9\% women and 14\% men), 28 and 35 years (12\% women and 13\% men), and over 35 years (26\% women and 15\% men).

All participants interviewed had a monthly income of at least the Brazilian minimum wage (1 salary), 21\% received from 1 to 2 salaries per month, 42\% received from 3 to 4 salaries, and 37\% received more than 4 salaries as their monthly income. Regarding schooling,
$0.5 \%$ of the interviewees were illiterate, $16 \%$ had not finished elementary school, $11.9 \%$ had not finished high school, $12.1 \%$ had not finished college, $8.8 \%$ had finished college, and $4.7 \%$ had earned a post graduate specialization. The majority of the participants have children that need to play in green open areas. In this sense, the UCLurban park holds great promise for providing this type of recreation. In addition, $75 \%$ of the residents of Passo Fundo use urban parks on a regular basis. This finding fits with the findings of [31] who researched the importance of urban parks in São Paulo State, Brazil. 68\% of those interviewed were also urban park users. However, 49\% of those interviewed in Passo Fundo had no previous knowledge of the UCL urban park. According to analytical methods by [29], these results lead to the conclusion that from the total of 184,869 residents of Passo Fundo, 94,283.19 would have some knowledge of the University City Lot Urban Park.

\subsection{Identification of the Urban Park Improvement Action Plan}

During 2010, professionals involved in the park planning and management were also interviewedto develop an action plan for the urban park. This item was complementary to the recovery project that was initiated in 2005. The following actions were proposed to achieve the environmental recovery of the park:

- Acquisition of infrastructural equipment for park users such as benches, garbage bins and street lights.

- Hiking trails and pedestrian pathways to enable the park use and appreciation while maintaining a minimum environmental impact.

- Implementation of a playground for recreation.

- Bike trails within the park limits.

- The addition of cultural spaces for reading and nature contemplation.

- Building a soccer field and sports area for recreational use by the community.

- Reforestation with native species and conservation of the existing green areas.

\section{Final Considerations}

This research highlights the importance of considering urban parks as areas to improve the people's quality of life, including the park in Passo Fundo city, RS State, Brazil. The UCL urban park was chosen as the objective of this study because of its location and the high negative environmental impact levels previously detected before this study. Much has been done, but this park is still in need for financial investment for total ecological recovery, maintenance and improvement for recreational use. The projects developed from 2005 to 2007 were not sufficient to fully recover the area due to the unplanned urbanization effect with negative impact to the soil, water, fauna, flora, and the nearby human community.

Despite the population growth and increased urbanization rates, there was also an increase on environmental awareness regarding the park situation. Park users and local community members have shown valid concerns about the environmental impact to this park and have identified the area as having an impact on their 
life quality. Such concerns were expressed through the local community association which supported and participated in environmental inventories. The association also helped with the planning and the implementation of recovery strategies as well as fundraising for the eventual purchase of recreational equipment. Overall, the park's preservation and recreational use were prioritized by the local community, allowing significant changes in the area.

Therefore, through this research, the mechanisms for environmental recovery of the UCL urban park were identified and justified to instigate continuous actions for the preservation and maintenance of urban parks. The community is a key element of this process and the most suitable development model comes as a consequence of the people's awareness about the ecosystem sustainability as a unique and unavoidable choice.

\section{References}

[1] Silva, F. B; Ferreira, W. R. (2003). Parques urbanos de Uberlândia: estudo de caso no parque municipal VictórioSiqueirolli. In: $2^{\circ}$ Simpósio Regional de Geografia, Uberlândia. Anais. Minas Gerais: UFU. p. 1-11.

[2] Scarim, P. C. (2000). Os resíduos de (re) espacialização industrial: a crise da cidade ou seu renascimento. Revista Geografares, Espírito Santo, Vitória, v.1, n.1, p.81-88.

[3] Seabra, O. C. L. (2000). Urbanização e fragmentação: a natureza natural do mundo. Revista Geografares, Espírito Santo, Vitória, v. 1, n. 1, p.72-80.

[4] Souza, M. L. de. (2002). Mudar a cidade: uma introdução crítica ao planejamento urbano e à gestão urbanos. Editora Bertrand Brasil, Janeiro. 560p.

[5] Rossetto, A. M. (2003). Proposta de um sistema integrado de gestão do ambiente urbano (SIGAU) para o desenvolvimento sustentável de cidades. Tese (Doutorado Engenharia de Produção), Programa de pós-graduação em Engenharia de Produção, Universidade Federal de Santa Catarina. 423p.

[6] Carlos, A. F. A. (1997). A cidade. $3^{\text {a }}$ edição, São Paulo: Contexto, 246p.

[7] Suertegaray, D. A. M; Schäeffer, N. O. (1993). Análise ambiental: a atuação do geógrafo para e na sociedade. In: Mesquita, O. V; Silva, S.T. Geografia e questão ambiental. Rio de Janeiro: IBGE, Departamento de Geografia.

[8] Schonardie, E. F. (3003). Dano ambiental: a omissão dos agentes públicos. Passo Fundo: UPF.

[9] Leff, E. (2003). A complexidade ambiental. São Paulo: Cortez, 342p.

[10] Melo, E. F. R. Q; Korf, E. P. (2008). Percepção ambiental de acadêmicos para impactos da disposição de resíduos sólidos urbanos. Artigo publicado no I Encontro Latino Americano de universidades sustentáveis, possibilidades e desafios, Universidade de Passo Fundo, p. 1-20.

[11] Chaffun, N. (1997). Dinâmica global e desafio urbano. In: Bonduki, N. (Org.) Habitat: as práticas bem-sucedidas em habitação, meio ambiente e gestão urbana nas cidades brasileiras, Editora Studio Nobel, São Paulo. 267p.

[12] New York City Soil Survey Staff. (2005). New York City Reconnaissance Soil Survey. United States Department of
Agriculture, Natural Resources Conservation Service, Staten Island. 57p.

[13] Spósito, E. S. (1996). A vida nas cidades. 3a edição, Editora Contexto, São Paulo. 96p.

[14] Araújo, G. H. S.; GUERRA, A. J. T.; ALMEIDA, J. R. (2007). Gestão Ambiental. Editora Bertrand, Rio de Janeiro. 246p.

[15] Almeida Filho, G. S. (2008). Processos erosivos urbanos. In:Poleto, Cristiano (org.) Ambiente e sedimentos. Porto Alegre: ABRH. p.39-63.

[16] Santos, M. (1996). A urbanização brasileira. Editora Hucitec, São Paulo. 99p.

[17] Scalise, W. (2002). Parques Urbanos - evolução, projeto, funções e uso. Revista Assentamentos Humanos, Marília, v. 4, n. 1, p17-24.

[18] Cribb, S. L. de S. P. (2008). Gestão das áreas de proteção ambiental e comunidades Locais: uma parceria necessária. Revista Eletrônica do Mestrado em Educação Ambiental, v. 20, n. 20, p. 350-371.

[19] Zamora, E. C.; Pombo, E. S.; Brassart, C. S.; Morencos, I. Z. (2003). Metodología para elestudio de los parques urbanos: laComunidad de Madrid. Geofocus Revista Internacional de Ciência y Tecnología de laInformacion Geográfica, v. 3, n. 3, p.160-185.

[20] Chiesura, A. (2004). The role of urban parks for the sustainable city. Landscape and Urban Planning, v. 68, n. 1, p. 129-138.

[21] Zanin, E. M.; Santos, J. E. dos.; Henke-Oliveira, C.(2005). Environmental Analysis and Zoning for an Urban Park Management Purpose. An International Journal: Brazilian Archives of Biology and Technology, v. 48, n. 4, p. 647-655.

[22] Angelis, B. L. D de.; Pereira, A. D.; Neto, G. A. de. (2008). Áreas verdes urbanas em parques industriais. In: Congresso Luso Brasileiro para o Planejamento Urbano, Regional, Integrado e Sustentável, $3^{\circ}$ Edição, 2008, Santos. Anais. São Paulo: PLURIS. p. 556-567.

[23] Felix, C. S.; Calciolari, G. F. de. M.; Une, K.; Brilhante, M. do. N.; Hatya, R. D.; Domingos, R. P.; Costa, V. P. (2008). Lazer, família e parques: O parque é um veículo de integração familiar? São Paulo: Escola de Artes, Ciências e Humanidades - EACH (Boletim técnico da Universidade de São Paulo). p. 1-17.

[24] Dainezi, P. M.; Carvalho, P. F. (2004). Pela revalorização das áreas verdes urbanas: o caso do parque Botafogo em Goiânia. In: Seminário de Pós Graduação em Geografia, 15, 2004, Rio Claro. Anais. São Paulo: AGETEO. p. 444-453.

[25] Oliveira, P. T. S. B. de.;Bitar, O. Y. (2009). Indicadores ambientais para o monitoramento de parques urbanos. Interfacehs - Revista de Gestão Integrada em Saúde do Trabalho e Meio Ambiente, v. 4, n. 2, p. 1-14.

[26] Peixoto, S.; Irving, M.; Prates, A. P. L.; Ferreira, I. V. (2005). Parque urbano da paz: a construção de um novo conceito no Parque Nacional da Tijuca. RDE - Revista de Desenvolvimento Econômico, v. 2, n. 11, p. 24-29.

[27] Neckel, A.; Pandolfo, A; Rojas, J. W. J.; Fanton, G.; Salles, M.; Pandolfo, L.; Kurek J. (2009). Recuperación Ambiental de un Área Verde Urbana. Revista de Ciencia y Tecnología, v.11, p.3341.

[28] Hildebrand, E.; Graça, L. R.; Hoeflich, V. A. (2002). "Valoração de Contingente” na avaliação econômica de áreas verdes urbanas. Revista Floresta, v. 32, n. 1, p. 121-132.

[29] IBGE. Censo. (2010). Dados disponíveis em: http:<//www.ibge.gov.br/cidadesat>. Acesso em: 01 Jan. 2011.

[30] SEPLAN (2009). Secretaria de Planejamento da Prefeitura Municipal de Passo Fundo-RS. Documentos do Setor. 18p.

[31] Whately, M.; Santoro, P. F.; Gonçalves, B. C.; Gonzatto, A. M. (2008). Parques urbanos municipais de São Paulo: subsídios para a gestão. São Paulo: Instituto Socioambiental. 124p. 